STUDI MANAGERIA: JURNAL MANAJEMEN PENDIDIKAN ISLAM

Volume 3, Nomor 1, Juni 2021

http://jurnal.radenfatah.ac.id/index.php/studiamanageria

\title{
Manajemen Pembelajaran Biologi Menggunakan Power Point
}

\author{
Dian Robian', Abdurahmansyah'2, Irham Falahudin ${ }^{3}$ \\ ${ }^{1}$ SMP Negeri 3 Lempuing, Mesuji, Indonesia \\ 2,3 Universitas Islam Negeri Raden Fatah Palembang, Sumatera Selatan, Indonesia \\ herlinadian@yahoo.com ${ }^{1}$
}

\begin{abstract}
This study aims to describe the management of biology learning using power points at Madrasah Aliyah Negeri 2 Ogan Komering Ilir which includes planning, implementation and evaluation. This research is a descriptive research with a qualitative approach. The subjects of this study were the principal, vice principal of the curriculum section, Biology subject teachers, staff staff, students related to the implementation of Biology learning. Data collection techniques used interviews, observation and documentation. Test the validity of the data using the source triangulation technique. The results showed that before teaching the teacher had to plan in advance the syllabus, prota, lesson plans and other learning tools. Implementation in biology learning must also be planned, so that students can receive learning effectively and efficiently so that learning objectives can be implemented. The evaluation carried out must also be in accordance with the planning and implementation, this learning evaluation can be carried out including collecting data about activities or giving questions to students, either individually or in groups and seeing the time efficiency of using the media used in an effort to achieve the learning objectives that have been set in the learning process. learning program. In the evaluation stage, the teacher first conveys all the material related to the subject matter. Furthermore, after the teacher gave the subject matter using the power point media used, the biology teacher directly gave questions to one of the students to answer questions that had to do with the material being taught using the power point.
\end{abstract}

\section{Keywords: Management, biology learning, power point media}

\begin{abstract}
Abstrak. Penelitian ini bertujuan untuk mendeskripsikan manajemen pembelajaran biologi dengan menggunakan power point di Madrasah Aliyah Negeri 2 Ogan Komering Ilir yang meliputi, perencanaan, pelaksanaan dan evaluasi. Penelitian ini merupakan penelitian deskriptif dengan pendekatan kualitatif. Subjek penelitian ini adalah kepala sekolah, wakil kepala sekolah bagian kurikulum, guru mata pelajaran Biologi, staf kepegawaian, siswa yang terkait dengan pelaksanaan pembelajaran Biologi.. Teknik pengumpulan data menggunakan wawancara, observasi dan dokumentasi. Uji Keabsahan data menggunakan teknik triangulasi sumber. Hasil penelitian menunjukan bahwa sebelum mengajar guru harus merencanakan terlebih dahulu silabus, prota, RPP dan perangkat pembelajaran lainnya. Pelaksanaan dalam pembelajaran biologi juga harus terencana, agar siswa dapat menerima pembelajaran dengan efektif dan efisien sehingga tujuan pembelajaran dapat dilaksanakan. Evaluasi yang dilakukan juga harus sesuai dengan perecanaan dan pelaksanaan, evaluasi pembelajaran ini dapat dilakukan diantaranya mengumpulkan data-data tentang aktivitas atau memberi pertanyaan kepada siswa bisa individu atau kelompok dan melihat efisiensi waktu penggunaan media yang digunakan dalam usaha mencapai tujuan pembelajaran yang telah di tetapkan dalam program pembelajaran. Dalam tahap mengevaluasi guru terlebih dahulu menyampaikan semua materi yang terkait dengan materi pelajaran. Selanjutnya setelah guru memberi materi pelajaran dengan menggunakan media power point yang digunakan maka guru biologi secara lisan langsung memberi pertanyaan kepada salah satu siswa untuk menjawab pertanyaan yang ada kaitannya dengan meteri yang diajarkan dengan menggunakan power point tersebut.
\end{abstract}

Kata Kunci: Manajemen, pembelajaran biologi, power point 


\section{PENDAHULUAN}

Manajemen adalah suatu proses penataan dengan melibatkan sumber-sumber potensial baik yang bersifat manusia maupun yang bersifat non manusia dalam rangka mencapai tujuan secara efektif dan efisien (Fattah, 2006: 15). Keberhasilan suatu sekolah dalam penyelenggaraan pendidikan dapat dikatan unggul apabila pengelolaan (manajemen) sekolah dikelola dengan benar dan sesuai prosedur yang ditentukan dalam kurikulum. Hal ini dikarenakan sekolah merupakan suatu institusi yang di dalamnya terdapat komponen guru, siswa, dan staf administrasi yang masing-masing mempunyai tugas tertentu dalam melancarkan program. Sehingga sekolah dituntut dapat menghasilkan lulusan yang mempunyai kemampuan akademis tertentu, keterampilan, sikap, dan mental serta berkepribadian dan berahklak mulia.

Sekolah efektif adalah sekolah yang memiliki standar pengelolaan yang baik dan benar, transfaran, responsible, dan akuntable, serta mampu memperdayakan setiap komponen penting disekolah, baik secara internal dan eksternal dalam rangka pencapaian tujuan visi misi sekolah. Maka pelaksanaan kegiatan pembelajaran di sekolah dalam prosesnya memerlukan tenaga terampil yaitu seorang pendidik yang disebut guru, karena pembelajaran berintikan adanya interaksi antara si pendidik dengan peserta didik. Interaksi tersebut adalah guru melakukan kegiatan yang disebut mengajar, sedangkan siswa melakukan kegiatan yang disebut belajar (Syaodih, 2010: 10). Maka dalam proses kegiatan pembelajaran sangat membutuhkan sumber daya manusia yang berkualitas, dan berpotensi dalam membangun potensi peserta didik, yang merupakan unsur penting dalam strategi kegiatan belajar mengajar untuk mencapai tujuan dan sasaran yang tepat dalam prosesnya.

Dalam kegiatan manajemen pembelajaran idealnya yang dilakukan guru adalah: Pertama, membuat perencanaan pembelajaran sebelum berhadapan dengan peserta didik dengan menentukan tema kemudia menentukan metrik atau menghubungkan potensi dasar (KD) dengan tema pembelajaran. Dengan merumuskan indikator pembelajaran, selanjutnya menyusun silabus pembelajaran. Kedua, mengorganisasikan serta menentukan sumber belajar, dan mengelompokkan materi ajar sebagai bahan ajar, menentukan kelas sehingga menjadikan lingkungan kelas yang kondusif, mengatur tempat duduk sesuai dengan banyaknya jumlah peserta didik, serta menyusun pelaksanaan pembelajaran yang digunakan untuk berhadapan dengan anak didik. Ketiga, melaksanakan kegiatan pembelajaran Biologi, yaitu menjabarkan silabus merupakan kegiatan awal yang harus ditempuh guru setiap kali pembelajaran. Fungsinya untuk menciptakan suasana awal pembelajaran yang efektif, 
(Manajemen Pembelajaran Biologi Menggunakan Power Point)

memungkinkan peserta didik mengikuti proses pembelajaran yang baik. Fakta dalam pelaksanaan menggunakan rencana pelaksanaan pembelajaran yang dibuat guru dengan masing-masing mata pelajaran menggunakan dua jam tatap muka, dengan menggunakan metode pembelajaran kelas aktif menjadikan kegiatan pembelajaran lebih aktif. Dalam pelaksanaannya direncanakan dengan langkah-langkah berikut: (a) kegiatan awal, (b) kegiatan inti, (c) kegiatan akhir, dan menentukan metode pembelajaran sesuai dengan yang telah ditentukan dalam rencana pelaksanaan pembelajaran (RPP). Dengan demikian guru Biologi mampu memutuskan apa yang harus diajarkan, bagaimana penyajian bahan ajar, metode dan media apa yang dapat digunakan peyampaian bahan ajar, serta bagaimana menekankan cara pengajaran agar peserta didik tertarik dan mudah memahami, mengerti apa yang diajarkan dan mampu menerapkan dalam kehidupan nyata. Dengan kondisi yang demikian maka manajemen pembelajaran menggunakan power point pada mata pelajaran Biologi dapat memberikan dorongan pada anak didik untuk belajar lebih kondusif, aktif, dan kreatif. Keempat, melaksanakan evaluasi (penilaian) merukan tanggung jawab berdasarkan kerangka kerja dalam pembelajaran. Evaluasi dilakukan untuk mengukur dari pelaksanaan kegiatan pembelajaran, menentukan sebab-sebab penyimpangan dan mengambil tindakan korektif dimana perlu dilakukan tes dan post test.

Dengan menerapkan manajemen pembelajaran dengan menggunakan power point sebagai media pembelajaran pada mata pelajaran Biologi di sekolah sangat membantu dan berguna untuk memenuhi kebutuhan sekolah dan kebutuhan anak didik dalam mencapai mutu pendidikan yang berkualitas. Juga dapat dijadikan acuan standar dalam usaha pencapaian tujuan pembelajaran, sehingga terarah dan terukur dalam kerjanya. Hal ini dikarenakan dalam kegiatan pembelajaran ada dua aspek yang akan dicapai, yaitu aspek didaktik dan metodik. Didaktik adalah ilmu yang berusaha menanamkan pengetahuan pada anak didik dengan cara yang cepat dan tepat, sehingga anak dengan mudah mencerna apa yang diperoleh selama proses belajar mengajar berlangsung. Sedangkan metodik adalah bagian dari didaktik yang membicarakan tentang pelaksanaan cara mengajar atau cara guru menyampaikan bahan pelajaran pada peserta didik (Zuhairini, 2004: 12).

Arsyad (2014: 2) menyatakan bahwa media pembelajaran dapat memperjelas penyajian pesan dan informasi sehingga dapat memperlancar dan meningkatkan proses dan hasil belajar. Manusia memiliki panca indra pada umumnya sehingga manusia yang memperoleh rangsangan yang berupa informasi kemudian informasi tersebut akan dimasukkan kedalam memori manusia. Jika manusia tidak merasa tertarik akan sebuah informasi maka 
informasi tersebut akan diabaikan begitu saja. Pentingnya penggunaan media dalam pembelajaran agar memuat informasi menjadi menarik sehingga tidak diabaikan oleh penerima pesan atau siswa. Melihat proses pelaksanaan media pembelajaran power point pada materi biologi di sekolah pada umumnya dan khususnya pada Madrasah Aliyah Negeri 2 Ogan Komering Ilir, dipandang perlu untuk ditingkatkan terutama cara atau metode campuran yang digunakan oleh guru ataupun respon para siswa dalam pengajaran tersebut. Hal ini dikarenakan hanya metode campuran dan sistem yang baik proses pengajaran biologi dapat berjalan dengan baik serta dapat dipahami dengan mudah oleh siswa. Penggunaan media pembelajaran power point pada materi biologi yang dikemukakan oleh pakar, pendidikan memungkinkan untuk digunakan di dalam pelajaran biologi.

Mengajarkan pembelajaran biologi itu hendaklah mengaktifkan semua panca indra anak didik, lidah harus dilatih dengan percakapan, mata dan pendengaran terlatih untuk membaca dan tangan harus terlatih untuk menulis dan mengarang kalau bisa seterusnya dalam mengembangkan pelajarannya. Namun yang penting untuk diperhatikan dalam media pembelajaran biologi adalah ketetapan dalam memilih, menentukan mana di antara sekian media pembelajaran itu dapat lebih cepat dan cocok untuk diterapkan dalam situasi pengajaran serta kemampuan untuk mengkombinasikan media-media yang telah diterapkan secara harmonis dan serasi, sebab masing-masing media pembelajaran memiliki kelebihan dan kekurangan.

Peneliti menganalisis bagaimana manajemen pembelajaran biologi dengan menggunakan power point di Madrasah Aliyah Negeri 2 Ogan Komering Ilir. Sebagai lokasi penelitian, merasa berkepentingan dan ingin serta mengamati bagaimana penggunaan media pembelajaran tersebut dapat di terapkan dan disesuaikan dalam pembelajaran biologi. Dilakukan penyusunan program pembelajaran tersebut adalah merupakan proses disiplin ilmu pengetahuan, realistis, sistem dan teknologi pembelajaran bertujuan agar pelaksanaan pembelajaran berjalan dengan efektif dan efisien.

Peningkatan mutu pembelajaran adalah hal utama yang dilakukan pada setiap lembaga pendidikan baik di sekolah umum maupun sekolah kejuruan dalam upaya memenuhi keinginan masyarakat serta mewujudkan cita-cita bangsa sebagaimana yang dikehendaki dari tujuan pendidikan nasional. Demikian pula yang dilakukan di Madrasah Aliyah Negeri 2 Ogan Komering Ilir merupakan objek dari penelitian ini. 
(Manajemen Pembelajaran Biologi Menggunakan Power Point)

\section{KAJIAN LITERATUR}

Manajemen adalah sebuah proses dalam perencanaan untuk mencapai tujuan tertentu. Istilah manajemen mengandung tiga pengertian, pertama manajemen sebagai suatu proses, kedua manajemen sebagai kolektivitas orang-orang yang melakukan aktivitas manajemen, dan ketiga manajemen sebagai suatu seni (art) dan sebagai suatu ilmu (Mustari, 2014: 1). Setelah melihat pengertian manajemen maka nampak jelas bahwa setiap organisasi pendidikan seperti sekolah akan sangat memerlukan manajemen untuk mengatur/mengelola kerjasama yang terjadi agar dapat berjalan dengan baik dalam pencapaian tujuan, untuk itu pengelolanya musti berjalan secara sistematis melalui tahapan-tahapan dengan diawali oleh suatu rencana sampai tahapan berikutnya yaitu melaksanakan evaluasi setelah proses pembelajaran dengan menunjukan suatu keterpaduan dalam prosesnya, dengan mengingat hal itu, maka makna pentingnya manajeman semakin jelas bagi kehidupan manusia termasuk bidang pendidikan.

Salah satu fungsi penting dari manajemen di sekolah adalah berkaitan dengan proses pembelajaran hal ini mencakup mulai dari aspek persiapan kegiatan perencanaan pembelajaran, mengorganisasian pembelajaran, pelaksanaan pembelajaran sampai dengan akhir kegiatan melakukan evaluasi diakhir proses kegiatannya untuk melihat kualitas dan mengkoreksi dari suatu proses tersebut dalam hubungan ini, sekolah sebagai suatu lembaga pendidikan yang melakukan kegiatan/proses pembelajaran jelas perlu mengelola kegiatan tersebut dengan baik karena proses belajar mengajar ini meruapakan kegiatan utama dari suatu sekolah. Manajemen di sekolah secara langsung akan mempengaruhi dan menentukan efektif tidaknya kurikulum, berbagai peralatan belajar, waktu mengajar, dan proses pembelajaran. Dengan demikian, upaya peningkatan kualitas pendidikan harus dimulai dengan pembenahan manajemen sekolah, disamping peningkatan kualitas guru dan pengembangan sumber belajar.

Pembelajaran merupakan suatu usaha sadar guru/mengajar untuk membantu siswa atau anak didiknya agar mereka dapat belajar sesuai dengan kebutuhan dan minatnya. Dengan kata lain pembelajaran adalah usaha-usaha yang terencana dalam memanipulasi sumber-sumber belajar agar terjadi proses belajar dalam diri siswa (Mustari, 2014: 5). Secara lebih khusus, pengertian media dalam proses belajar mengajar cendrung diartikan sebagai alat-alat grafis, foto grafis, atau elektronis untuk menangkap, memproses, dan menyusun kembali informasi visual atau verbal. Berdasarkan uraian tersebut, maka dapat disimpulkan bahwa media pembelajaran adalah alat yang dapat membantu proses belajar mengajar dan berfungsi untuk memperjelas makna 
pesan yang disampaikan, sehingga dapat mencapai tujuan pembelajaran dengan lebih baik dan sempurna.

Pembelajaran yang diidentikan dengan kata "mengajar" bersasal dari kata dasar "ajar" yang bearti petunjuk yang diberikan kepada orang supaya diketahui (dituruti) ditambah dengan awalan "pe" dan akhiran "an" menjadi "pembelajaran", yang berati proses perbuatan, cara mengajarkan sehingga anak didik mau belajar (Hamzah, 2012: 142). Pembelajaran juga dapat didefinisikan sebagai suatu sistem atau proses membelajarkan subjek didik atau pembelajar yang direncanakan atau didesain, dilaksanaka, dan di evaluasi secara sistematis agar subjek didik atau pembelajar dapat mencapai tujuantujuan pembelajaran secara efektif dan efisien (Kokom, 2011: 3). Pembelajaran dapat dipandang dari dua sudut, pertama pembelajaran dipandang sebagai suatu sistem, pembelajaran terdiri dari jumlah komponen yang terorganisasi antara lain tujuan pembelajaran, materi pembelajaran, strategi dan metode pembelajaran, media pembelajaran, pengorganisasian kelas, evaluasi pembelajaran dan tindak lanjut pembelajaran (remedial dan pengayaan). Kedua, pembelajaran dipandang sebagai suatu proses, maka pembelajaran merupakan rangkaian upaya atau kegiatan guru dalam membuat siswa belajar. Proses tersebut meliputi: a) persiapan, dimulai dari merencanakan program tahunan, semester, dan penyusunan perencana pelaksanaan pengajaran serta penyiapan perangkat kelengkapannya, antara lain berupa alat peraga dan alat-alat evaluasi. b) melaksanakan kegiatan pembelajaran dengan mengacu pada persiapan pembelajaran yang telah dibuat guru. c) menindak lanjuti pembelajaran yang telah dikelola oleh guru. Kegiatan pasca pembelajaran ini dapat berbentuk pengayaan atau remedial bagi siswa yang mengalami kesulitan belajar (Kokom, 2011: 3-4).

Pembelajaran adalah suatu usaha yang sengaja melibatkan dan menggunakan pengetahuan professional yang dimiliki guru untuk mencapai tujuan kurikulum. Dengan demikian, dapat dikatakan bahwa pembelajaran adalah suatu aktivitas yang dengan sengaja untuk memodifikasi berbagai kondisi yang diarahkan untuk tercapainya suatu tujuan yang diinginkan. Untuk mencapai tujuan tersebut peserta didik diajarkan atau dilatih dalam meningkatkan keyakinan, pemahaman, penghayatan dan pengalaman terhadap ajaran-ajaran pendidikan, dalam hal ini dipersiapkan oleh pendidik mulai dari merencanakan kegiatan yang akan dilakukan, lalu mengorganisasikan bahan ajar yang akan disampai, sampai dengan pelaksanaan yang akan dilakukan dalam kegiatan yang dirancang dari awal pertemuan sampai akhir kegiatan, dan setelah proses kegiatan dilakukan 
(Manajemen Pembelajaran Biologi Menggunakan Power Point)

evaluasi sebagai tanggung jawab kerja guru dan sebagai bahan koreksi kalau ada penyimpangan dari proses kegiatan pembelajaran.

Dalam kata lain media adalah wadah dari pesan yang oleh sumbernya ingin diteruskan kepada sasaran atau penerima pesan tersebut. Apabila dipahami secara garis besar maka media adalah manusia, materi, atau kejadian yang membangun suatu kondisi atau membuat siswa mampu memperoleh pengetahuan, keterampilan, atau sikap. Dalam pengertian ini guru, buku, teks dan lingkungan sekolah merupakan media (Sudjipto, 2013: 7). Media pembelajaran berbantuan komputer lebih memotivasi siswa karena dalam media pembelajaran berbantuan komputer mencakup audio visual dan interaktif (Sunyoto, 2012). Menurut Barika (2010) bahwa media pembelajaran dapat mengkonkretkan ideide atau gagasan yang bersifat konseptual sehingga mengurangi kesalahpahaman siswa dalam mempelajarinya dan meningkatkan kemampuan kognitif siswa itu sendiri.

Media pembelajaran adalah sarana untuk meningkatkan kegiatan proses belajar mengajar mengingat banyaknya bentuk-bentuk media tersebut, maka penulis harus memilihnya dengan cermat sehingga penulis dapat menyimpulkan bahwa power point dapat digunakan sebagai media pembelajaran. Hal ini dikarenakan media pembelajaran dengan mengunakan power point dapat mendukung dalam proses belajar-mengajar. Sehubungan dengan itu peneliti tertarik menggunakan media power point sebagai media pembelajarannya.

Menurut Darmawan power point merupakan suatu softwere yang dirancang khusus untuk mampu menampilkan program multimedia dengan menarik, mudah dalam pembuatan, mudah dalam penggunaan dan relative murah, karena tidak membutuhkan bahan baku selain alat untuk menyimpan data (Darmawan, 2012: 301). Jadi media pembelajaran power point merupakan program aplikasi yang ada di komputer yang dapat dimanfaatkan sebagai media pembelajaran yang dapat menarik perhatian siswa dalam proses pembelajaran sehingga siswa berminat untuk belajar. Media power point bukan hanya dapat digunakan untuk persentasi semata namun juga bisa menjadi media dalam proses pembelajaran yang dilakukan guru dengan menampilkan garis besar materi atau poin-point materi karena kekuatan ada pada point-point materi yang disajikan dalam bentuk teks dan gambar, clip art, shape animasi dll hanya untuk memperkuat dari point-point materi tersebut.

\section{METODE PENELITIAN}

Pendekatan ini menggunakan pendekatan deskriptif kualitatif, yaitu penelitian yang menghasilkan penemuan-penemuan yang dapat dicapai 
(diperoleh) dengan menggunakan prosedur-prosedur yang tertulis atau dengan cara dari kualifikasi (pengukuran). Penelitian kualitatif tidak selalu mencari sebab akibat namun, lebih berupaya memahami situasi tertentu, dengan bentuk penelitian case study (study kasus) yaitu suatu penelitian secara intensif, terperinci dan mendalam suatu organisasi. Penelitian kualitatif memiliki sejumlah ciri-ciri yang membedakan dengan jenis penelitian lainnya. Menggunakan latar alamiah (naturalistik), manusia sebagai alat (instrumen), metode kualitatif (wawancara, pengamatan atau dokumen), bersifat deskriktif, analisis data secara induktif, teori dari dasar (grounded theory), lebih mementingkan proses daripada hasil, adanya batasan yang ditentukan oleh fokus, adanya kriteria khusus untuk keabsahan data (mendefinisikan, validitas, rehabilitas, dan objektifitas, desain yang bersifat sementara dan hasil penelitian dapat diimplementasikan dan disepakati bersama) (Moleong, 2013: 9).

Dalam penelitian kualitatif kedudukan penelitian sangat penting, hal ini sesuai dengan yang dikemukakan Lexy Moleong bahwa kedudukan peneliti dalam penelitian kualitatif harus memerlukan data yang akurat hal ini dikarenakan peneliti berperan mulai dari merencanakan, melakukan pengumpulan data, menganalisis data, menafsirkan data, sampai membuat laporan penelitian tersebut. Hal ini dikarenakan penelitian merupakan instrumen penting dalam penelitian kualitatif, peneliti dalam hal ini berperan segalanya dalam proses penelitian (Moleong, 2013: 121). Untuk itu kegiatan penelitian ini adalah mendeskripsikan secara intensif dan terperinci tentang gejala dan fenomena yang diteliti yaitu mengenai masalah yang berkaitan dengan objek penelitian ini maka, penelitian ini menggunakan pendekatan deskriptif analisis, karena hasil penelitian ini berupa data deskriptif dalam bentuk kata tertulis atau lisan serta hal-hal yang berkaitan dan yang diperlukan dalam penelitian. Teknik pengumpulan data menggunakan wawancara, observasi dan dokumentasi. Uji Keabsahan data menggunakan teknik triangulasi sumber.

\section{HASIL DAN PEMBAHASAN}

Berkaitan dengan penggunaan power point dalam pembelajaran biologi, Peneliti melaksanakan penelitian ini pada hari Sabtu tanggal 11 Mei 2019 di Madrasah Aliyah Negeri 2 Ogan Komering Ilir guna memperoleh data lapangan yang sebanyak-banyaknya sesuai dengan fokus penelitian. Peneliti melakukan pengambilan sumber data dengan memulai pemilihan informan satu ke informan lainnya yang meliputi Kepala Madrasah, wakil kepala bidang 
(Manajemen Pembelajaran Biologi Menggunakan Power Point)

kurikulum, guru biologi dan siswa serta komponen yang ada dan bisa memberi keterangan tentang fenomena penelitian yang sedang diteliti.

Berikut ini disampaikan data hasil penelitian dan data lengkap yang berkaitan dengan fokus penelitian, yakni:

\section{Perencanaan penggunaan power point dalam pembelajaran biologi di Madrasah Aliyah Negeri 2 Ogan Komering Ilir.}

Setelah peneliti melakukan penelitian di lapangan, maka pada fokus pertama diperoleh beberapa temuan. Pertama, Guru mempelajari silabus, membuat Rencana Pelaksanaa Pembelajaran (RPP) dan menyiapkan materi yang akan disampaikan. Temuan di atas berdasarkan hasil wawancara yang dilakukan oleh peneliti kepada guru biologi di Madrasah Aliyah Negeri 2 Ogan Komering Ilir, yaitu kesiapan guru dalam mengajar juga harus direncanakan dengan matang, agar ketika pembelajaran berlangsung tidak terjadi kesalahan, kesiapan ini berfungsi agar proses pembelajaran itu terarah. Ada beberapa perencanaan yang dilakukan sebelum proses belajar mengajar berlangsung antara lain mempelajari silabus, membuat RPP. Sebelum kegiatan pembelajaran sesama guru mata pelajaran terlebih dahulu menyusun Rencana Pelaksanaan Pembelajaran (RPP). Kemudian pemilihan media yang sesuai dengan materi. Hal ini dikarenakan pemilihan media akan mempengaruhi minat belajar siswa. Media yang biasanya digunakan sebagai media pembelajaran adalah power point. Dalam pembuatanannya power point mengacu pada materi yang akan disampaikan.

Tidak semua penjelesan dimasukan ke power point. Akan tetapi, hanya poin-poinnya saja yang di masukkan ke power point, sedangkan menurut Bapak Ihsan yaitu Penyusunan Rencana Pelaksanaan Pembelajaran (RPP) sangatlah penting sebelum memulai pembelajaran. Agar kegiatan belajar mengajar menjadi terarah. Apalagi dibantu dengan power point menyampaikan materi lebih mudah lebih gampang lagi serta mampu melatih keaktifan belajar siswa yang bertujuan untuk meningkatkan kecerdasan siswa.

Silabus merupakan rencana pembelajaran pada suatu dan atau kelompok mata pelajaran atau tema tertentu yang mencakup standar kompetensi, kompetensi dasar, materi pokok pembelajaran, kegiatan pembelajaran, indikator, penilaian, alokasi waktu dan sumber atau bahan atau alat belajar (Junaedi, 2007: 127). Berdasarkan temuan penelitian di atas dapat disimpulakan bahwa persiapan guru sebelum melakukan proses pembelajaran itu sangat penting agar kegiatan belajar mengajar berjalan dengan lancar serta untuk menghindari kerancuan ketika proses belajar mengajar berlangsung, maka guru perlu menyusun RPP agar tujuan pembelajaran tersebut akan tercapai secara maksimal. Apalagi dengan 
dukungan media pembelajaran yaitu media power point khususnya pembelajaran biologi, guru akan lebih mudah untuk menyampaikan materinya. Temuan penelitian yang Kedua, Guru memilih media khususnya power point, perlu memperhatikan kecermatan, ketepatan dan tujuan pembelajaran yang ingin dicapai dengan melihat kondisi siswa dan ketersediaan media pembelajaran.

Temuan di atas berdasarkan hasil wawancara yang dilakukan oleh peneliti kepada guru biologi di Madrasah Aliyah Negeri 2 Ogan Komering Ilir, yaitu beberapa pertimbangan yang mana ini sangat perlu untuk diperhatikan guna untuk kecermatan dan ketepatan dalam memilih media pembelajaran diantaranya: a. Media yang dipilih sesui dengan materi yang diajarkan $b$. Ketersedian media di sekolah c. Media yang dipilih seharusnya bisa menjelaskan apa yang akan disampaikan ke siswa d. Guru juga harus bisa menggunakan media tersebut e. Biaya yang digunakan dalam memanfaatkan media harus seimbang dengan hasil yang akan dicapai.

Berdasarkan penemuan penelitian di atas dapat disimpulkan bahwa dalam pembelajaran, pemilihan media sangat penting hal ini terkait dengan materi yang akan disampaikan serta tujuan dari pembelajaran. Pemilihan media didasarkan pada hasil analisis yang tajam. Agar media yang digunakan tepat sasaran dan sesuia dengan keperluan, sehingga memungkinkan terjadi interaksi yang baik antara siswa dengan media yang digunakan oleh guru. Banyaknya ragam media yang tersedia, mengharuskan para guru perlu memilih media yang digunakan karena setiap media memiliki kelebihan dan kekurangan masing-masing. Sedangkan media yang tidak tepat pada sasaran tidak akan memberikan hasil memuaskan, bahkan mungkin sebaliknya. Jadi pemilihan media pembelajaran dimaksudkan agar guru dapat menentukan media yang tepat dan sesuai dengan kondisi siswa.

Menurut Santoso, media yang efektif adalah media yang mampu mengkomunikasikan sesuatu yang ingin disampaikan oleh pemberi pesan atau sumber dapat ditangkap secara utuh oleh penerima pesan tersebut. Oleh karena itu dalam merancang Kegiatan Belajar Mengajar hendaknya dipilih pula media yang benar-benar efektif dan efisien atau merancang media sendiri (media by design) sehingga dapat menyampaikan pesan pembelajaran yang akhirnya terbentuk kompetensi dari siswa (Santoso, 2002).

Berdasarkan temuan ketiga, Sebelum penggunaan power point guru dapat mengenal karakteristik siswa, karena dalam kegiatan pembelajaran siswa mempunyai latar yang berbeda-beda serta kondisi yang berubah-ubah. Temuan di atas berdasarkan hasil wawancara yang dilakukan oleh peneliti kepada guru biologi di Madrasah Aliyah Negeri 2 Ogan Komering Ilir, yaitu 
(Manajemen Pembelajaran Biologi Menggunakan Power Point)

bahwa siswa harus menjadi perhatian utama dalam pembelajaran termasuk kesiapannya dalam mengikuti pelajaran yang meliputi ada tidaknya motivasi, keadaan dan suasana kelas yang mendukung pembelajaran, kemampuan anak-anak untuk melaksanakan kegiatan tersebut sehingga sebelum menggunakan media power point selalu memperhatikan kondisi dan kemampuan siswa. Kesiapan siswa dalam mengikuti pelajaran tentu akan mempengaruhi kegiatan dan hasil pembelajaran. Adakalanya anak-anak tidak siap untuk mengikuti pelajaran dengan menggunakan media pembelajaran yang dirancang sebelumnya, sehingga harus tanggap mengubah cara mengajar agar anak-anak dapat memahami sepenuhnya materi yang diajarkan.

Berdasarkan temuan di atas dapat disimpulkan bahwa kesiapan siswa dalam mengikuti pembelajaran akan mempengaruhi kegiatan pembelajaran. Maka dari itu sebelum menggunakan media power point, guru memperhatikan kondisi dan kemampuan siswa dalam menangkap materi yang akan disampaikan oleh guru, dengan cara itu tujuan pembelajaran akan tercapai.

Lingkungan kelas dan ketersediaan media pembelajaran di kelas merupakan hal yang berpengaruh terhadap kemampuan peserta didik dalam menerima materi pembelajaran, dimana peserta didik didorong dengan kesadaran sendiri untuk belajar bukan mengikuti alur yang dibuat oleh guru. Dengan demikian peserta didik akan membangun pengetahuan sendiri melalui media yang dibuat dan dimanfaatkan oleh guru didalam proses pembelajaran. Hal ini menjelaskan bahwa ketersediaan media pembelajaran sangat penting dan berpengaruh terhadap proses pembelajaran.

Media pembelajaran merupakan satu diantara kunci keberhasilan dalam proses pembelajaran di kelas dimana media merupakan alat yang digunakan untuk menyampaikan pesan dari guru ke peserta didik agar memperoleh informasi melalui media yang digunakan. Adanya media pembelajaran diharapkan bahwa penyajian materi belajar lebih jelas tidak bersifat verbalistis. Bahan-bahan dapat disajikan dengan suatu rangkaian peristiwa yang disederhanakan atau diperkaya sehingga kegiatan belajar tidak merupakan uraian yang membosankan siswa.

Berdasarkan temuan penelitian yang keempat, guru perlu mengetahui karakteristik dari power point agar proses belajar mengajar bisa berjalan secara efektif dan efisien. Temuan di atas dari hasil wawancara yang dilakukan oleh peneliti kepada guru guru biologi di Madrasah Aliyah Negeri 2 Ogan Komering Ilir, yaitu bahwa media pembelajaran dengan power point itu adalah media pembelajaran yang menggunakan alat elektronik, yakni program dalam komputer. Penggunaan power point dalam kegiatan belajar dapat mempermudah siswa dalam memahami suatu materi pelajaran terutama 
dalam presentasi. Ciri khas media pembelajaran power point dalam pembelajaran biologi, seperti biasanya guru memberikan pemahaman kepada siswa dengan menampilkan slide-slide dalam program komputer dan penjelasan-penjelasan dengan tujuan supaya siswa mudah menerima materi yang diajarkan.

Dapat disimpulkan bahwa karakteristik dari media power point yaitu penyajian materi pelajaran terutama pendidikan agama Islam dengan menggunakan program dalam komputer yang dirancang berupa tampilantampilan slide, sehingga mempermudah guru dan siswa dalam kegiatan belajar mengajar serta tampilannya pun dapat dibuat semenarik mungkin.

\section{Pelaksanaan penggunaan power point dalam pembelajaran biologi di Madrasah Aliyah Negeri 2 Ogan Komering Ilir.}

Setelah peneliti melakukan penelitian di lapangan, maka pada fokus kedua diperoleh beberapa temuan. Pertama, guru biologi menggunakan media power point sebagai sarana penunjang pembelajaran. Temuan di atas berdasarkan hasil wawancara yang dilakukan oleh peneliti kepada guru biologi di Madrasah Aliyah Negeri 2 Ogan Komering Ilir, yaitu bahwa penggunaan cukup berjalan lancar, namun penggunaannya masih bergantian. Hal ini karena keterbatasan media khususnya media power point yang memerlukan beberapa perangkat yaitu Laptop dan LCD. Sedangkan disekolah Madrasah Aliyah Negeri 2 Ogan Komering Ilir, LCD masih berpindah-pindah karena. Oleh Karena keberadaan power point ini sangat penting, disamping dapat membantu dalam menyampaikan materi ini juga befungsi untuk memudahkan pemahaman siswa dan membangkitkan motivasi karena tidak hanya cerita saja tetapi juga bisa mendengar, melihat adakalnya yang dipraktekkan.

Sedangkan menurut siswa bahwa hanya sebagian guru yang menggunakan power point, karena semua ruangan kelas belum difasilitasi LCD proyektor yang disebabkan oleh ketersediaan LCD yang terbatas. Salah satu guru yang sudah menggunakan power point yaitu pada pembelajaran biologi. Pada pembelajaran biologi, guru sudah dapat mengoperasikan denga baik penggunaaan power point. Berbeda dengan pembelajaran yang tidak menggunakan media, hanya berupa metode ceramah yang menyebabkan ketidaktertarikan dalam pembelajaran.

Thobroni mengatakan media pembelajaran dapat bermanfaat dalam proses belajar mengajar yaitu media pembelajaran dapat memperjelas penyajian pesan, menarik perhatian siswa, meningkatkan hasil belajar, mengatasi keterbatasan indera, ruang dan waktu serta memberikan kesamaan pengalaman kepada siswa (Mustofa, 2011: 213). 
(Manajemen Pembelajaran Biologi Menggunakan Power Point)

Berdasarkan temuan penelitian di atas dapat disimpulkan bahwa pembelajaran biologi di MAN 2 OKI telah menggunakan power point sebagai media pembelajaranya. Walaupun penggunaannya masih sebatas pilihan, akan tetapi keberadaan power point sebagai media pembelajaran mempermudah guru menyampaikan materi dan dapat meningkatkan pemahaman siswa terhadap materi yang disampaikan guru. Power point juga dapat dikatakan suatu cara guru untuk menghadapi siswa yang bosan, malas, ngantuk dan lain-lain pada waktu proses pembelajaran berlangsung. Jadi dengan adanya power point dalam proses pembelajaran sangatlah penting. Oleh karena itu, guru dituntut untuk bisa mendorong dan merangsang siswa agar memiliki kemaun belajar salah satunya dengan penggunaan power point dalam pembelajaran.

Sesuai temuan penelitian yang Kedua, dalam penggunaan power point guru mempunyai peranan dalam pembelajaran diantaranya pengelolaan kelas, baik kondisi siswa maupun ruangan yang akan digunakan. Temuan di atas diperoleh dari hasil wawancara yang dilakukan oleh peneliti kepada guru biologi di Madrasah Aliyah Negeri 2 Ogan Komering Ilir yaitu bahwa guru yang tugasnya mengajar mempunyai peranan dalam pembelajaran diantaranya pengelolaan kelas, baik kondisi siswa maupun ruangan yang digunakan untuk kegiatan pembelajaran. Bertujuan agar terlaksana dengan baik dan tercapai tujuan pembelajaran.

Hasil temuan di atas dapat ditarik kesimpulan bahwa guru harus mampu mengkondisikan siswa agar tetap konsentrasi dalam belajar. Oleh karena itu, usaha guru dalam mengelola siswa menggunakan metode dan media pembelajaran yang sesui dengan materi, misalnya dengan penggunaan power point, dengan menggunakan media ini dapat memudahkan guru untuk menyampaikan materi. Selain itu guru harus lebih kreatif dalam pembuatan power point, sehingga siswa tidak akan bosan dan lebih tertarik dalam mengikuti pelajaran.

Berbagai tanggapan siswa tersebut sejalan dengan pendapat Bakrowi (2007) yang mengemukakan bahwa siswa menyukai animasi- animasi yang digunakan guru untuk mengkonkritkan pembelajaran. Begitu juga dengan Stith (2004) yang mengatakan bahwa siswa berperan lebih aktif dalam pembelajaran yang menggunakan sistem multimedia. Ketertarikan siswa terhadap media pembelajaran menjadikan siswa aktif berdiskusi dengan teman (Umar, 2013).

Dari temuan penelitian yang ketiga, respon siswa sangat senang setelah media power point digunakan pada pembelajaran, yang jelas dalam proses pembelajaran berjalan dengan lancar dan siswa bisa menerima materi yang 
disampaikan dengan baik. Temuan di atas berdasarkan hasil wawancara yang dilakukan oleh peneliti kepada guru biologi dan siswa di Madrasah Aliyah Negeri 2 Ogan Komering Ilir, yaitu bahwa respon siswa sangat senang setelah power point digunakan pada pembelajaran, yang jelas dalam proses pembelajaran berjalan dengan lancar dan siswa bisa menerima materi yang disampaikan dengan baik. Sedangkan menurut siswa bahwa merasa senang dengan diterapkannya media power point pembelajaran pada pokok bahasan tertentu.

Berdasarkan hasil wawancara dengan siswa kelas X IPA 1 mengatakan bahwa pelaksanaan pembelajaran di kelas sangat menarik dengan adanya guru menggunakan power point membuat siswa tertarik dan memperhatikan pembelajaran dengan sungguh-sungguh. Guru juga melibatkan siswa dalam menggunakan power point. Hal ini membuat siswa menjadi semangat dalam belajar.

Dari keterangan di atas bahwa di Madrasah Aliyah Negeri 2 Ogan Komering Ilir khususnya pembelajaran biologi, penggunaan power point dalam menyampaikan materi sangat perlu karena disamping mempermudah dalam penyampaian materi, media ini juga menimbulkan dampak yang positif terhadap daya minat belajar siswa. Mengingat pembelajaran biologi kurang disukai siswa, adanya strategi yang baru dengan menggunakan media dalam penyampaian materi itu lebih membantu untuk mencapai suatu tujuan pembelajaran biologi.

\section{Evaluasi penggunaan power point dalam pembelajaran biologi di Madrasah Aliyah Negeri 2 Ogan Komering Ilir.}

Setelah peneliti melakukan penelitian di lapangan, maka pada fokus ketiga diperoleh beberapa temuan. Pertama, dalam mengevaluasi media power point ini cukup sederhana bahwasannya evaluasi pembelajaran ini dapat dilakukan diantaranya mengumpulkan data-data tentang aktivitas atau memberi pertanyaan kepada siswa bisa individu atau kelompok dan melihat efisiensi waktu penggunaan media yang digunakan dalam usaha mencapai tujuan pembelajaran yang telah di tetapkan dalam program pembelajaran.

Temuan di atas berdasarkan hasil wawancara yang dilakukan oleh peneliti kepada kepada guru biologi di Madrasah Aliyah Negeri 2 Ogan Komering Ilir, yaitu bahwa dalam mengevaluasi power point ini cukup sederhana. Dikatakan sederhana mengutarakan bahwasannya evaluasi pembelajaran ini dapat dilakukan diantaranya mengumpulkan data-data tentang aktivitas atau memberi pertanyaan kepada siswa bisa individu atau kelompok dan melihat efisiensi waktu penggunaan media yang digunakan 
(Manajemen Pembelajaran Biologi Menggunakan Power Point)

dalam usaha mencapai tujuan pembelajaran yang telah di tetapkan dalam program pembelajaran. Dalam tahap mengevaluasi guru terlebih dahulu menyampaikan semua materi yang terkait dengan materi pelajaran. Selanjutnya setelah guru memberi materi pelajaran dengan menggunakan power point yang digunakan maka guru biologi secara lisan langsung memberi pertanyaan kepada salah satu siswa untuk menjawab pertanyaan yang ada kaitannya dengan meteri yang diajarkan dengan menggunakan power point tersebut.

Selanjutnya guru bisa menganalisis dan mengevaluasi sendiri dengan data yang diperoleh dari pertannyaan yang dilemparkan kepada siswa apakah materi yang di ajarkan dengan menggunakan media tersebut bisa dicerna secara maksimal atau sebaliknya.

Peran media antara lain: 1) melancarkan informasi dan pesan sehingga berdampak kepada peningkatan hasil belajar, 2) memunculkan motivasi belajardengan meningkatan, 3) mengarahkan perhatian siswa,dan 4) memberikan solusi karena terbatasnya indera, ruang serta waktu. Sedangkan fungsi media pembelajaran yaitu: 1) memberikan kemudahan siswa dalam belajar, 2) mengubah pengalaman abstrak menjadi konkret, 3) proses belajar mengajar tidak membosankan, 4) meningkatkan minat, perhatian siswa pada proses belajar (Umar, 2013).

Dapat disimpulkan bahwa evaluasi digunakan untuk mengukur sejauh mana tingkat pemahaman siswa terhadap materi yang telah disampaikan oleh guru. Salah contohnya RA guru mata pelajaran Biologi memberikan tanya jawab, soal, atau kuis interaktif. Sebelum melaksanakan evaluasi media pembelajaran, guru RA harus mengetahui cara agar mendapatkan hasil evalusi tersebut yaitu menyampaikan materi dengan menggunakan power point kemudian guru RA memberikan umpan balik kepada siswa berupa pertanyaan dan siswa menjawabnya. Dari pertanyaan yang ditujukan guru RA kepada siswa dan dari disinilah guru RA mengevaluasi apakah media yang digunakan efektif atau tidak.

\section{KESIMPULAN}

Dengan adanya manajemen pembelajaran biologi dengan menggunakan power point dapat berjalan degan lebih baik lagi. Pertama guru harus merencanakan terlebih dahulu sebelum mengajar seperti menyiapkan silabus, prota, RPP dan perangkat pembelajaran lainnya. kemudian guru juga menyiapkan power point yang akan digunakan. Selain itu, guru juga menyiapkan perangkat pendukung seperti LCD dan monitor. Selanjutnya, guru dapat masuk ke materi yang akan diajarkan. Pelaksanaan dalam pembelajaran 
$\overline{\text { biologi juga harus terencana, agar siswa dapat menerima pembelajaran }}$ dengan efektif dan efisien sehingga tujuan pembelajaran dapat dilaksanakan. Evaluasi yang dilakukan juga harus sesuai dengan perecanaan dan pelaksanaan, evaluasi pembelajaran ini dapat dilakukan diantaranya mengumpulkan data-data tentang aktivitas atau memberi pertanyaan kepada siswa bisa individu atau kelompok dan melihat efisiensi waktu penggunaan media yang digunakan dalam usaha mencapai tujuan pembelajaran yang telah di tetapkan dalam program pembelajaran. Dengan adanya hasil evaluasi dapat diketehui pembelajaran biologi dengan menggunakan power point sangat efektif dan dapat membuat siswa menjadi aktif dalam mengikuti pembelajaran di Madrasah Aliyah Negeri 2 Ogan Komering Ilir.

\section{DAFTAR PUSTAKA}

Arsyad, A. (2014). Media Pembelajaran. Jakarta: Rajawali Pers.

Bakrowi. 2007. Microsoft Officer Power Point sebagai Media Pembelajaran Materi Unsur, Senyawa, dan Campuran Berbasis STAD. Jurnal Pendidikan Inovatif. Volume 3. Nomor 1. September/2007.

Barika, V., Bagarukayo, E. 2010. "A Multi- Experimental Study on the Use of Multimedia Instructional Materials to Teach Technical Subjects". Journal of STEM Education. Vol 1\#2 Special Edition 2010

Darmawan, dkk. (2012). Teknologi Pembelajaran. Bandung: PT. Remaja Rosadakarya

Fattah, N. (2006). Landasan Manajemen Pendidikan. Bandung: Remaja Rosda Karya.

Hamzah, U. ( 2012). Perencanaan Pembelajaran. Jakarta: Bumi Aksara.

Junaedi, K. d. (2007). Kurikulum Tingkat Satuan Pendidikan Konsep dan Implementasinya di Madrasah . Jogjakarta: Nuansa Aksara.

Kokom, K. (2011). Pembelajaran Kontekstual Konsep dan Aplikasi. Bandung: Refika Aditia.

Moleong, J. L. (2013). Metodologi Penelitian Kulitatif. Bandung: Remaja Rosada Karya.

Mustari, M. (2014). Manajemen Pendidikan. Jakarta: Rajawali Pers.

Santoso. (2002). Pemilihan dan Pengembangan Media Pembelajaran. Semarang: Proyek Peningkatan Tenaga Kependidikan dan Non Kependidikan Menengah Dinas Pendiidkan Provinsi Jawa Tengah Kerja Sama Dengan UPT SBM Universitas Negeri Semarang.

Stith, Bradley, J. 2004. Use of Animation in Teaching Cell Biology. Journal of Cell Biology Education. Vol.3, halaman 181- 188 
(Manajemen Pembelajaran Biologi Menggunakan Power Point)

Sunyoto. 2012. Penggunaan Video Animasi Untuk Meningkatkan Prestasi Belajar Siswa Dalam Pembelajaran Kompetensi Sistem Starter. Automotive Science and Education Journal. Vol.1, No.1 (1)/2012

Sudjipto, C. K. (2013). Media Pembelajaran. Bogor: Ghalia Indonesia.

Umar. (2013). Peran dan Fungsinya dalam Pembelajaran. Jurnal Tarbawiyah. (10). 
$\longrightarrow$ 